\title{
Serotyping of Campylobacter jejuni/coli
}

\author{
JD ABBOTT, BAS DALE, JOAN ELDRIDGE, DM JONES, \\ AND ENID M SUTCLIFFE \\ From the Public Health Laboratory, Withington Hospital, Manchester M20 8LR, UK
}

SUMMARY Antisera were prepared from strains of Campylobacter jejuni/coli isolated from patients in six outbreaks of enteritis. Bactericidal antibodies, and agglutinating antibodies to heat-labile and heat-stable antigens, were demonstrated. These reactions were used to type a number of strains isolated from patients in each outbreak, and to distinguish 'epidemic' from 'non-epidemic' strains.

The ability to distinguish between strains of Campylobacter jejuni/coli will facilitate the study of the epidemiology of this common cause of gastrointestinal infection. Methods to achieve this include antigenic typing and biotyping. ${ }^{1}$ We have investigated further the use of simple serological methods to serotype strains of campylobacter causing human disease.

\section{Material and methods}

\section{CULTURES}

Each of six outbreaks studied was numbered consecutively, and the same number was given to a representative strain isolated from the faeces of a patient involved in the outbreak. Most of these outbreaks were thought to be milk-borne, and in one outbreak isolates from cows were also examined.

\section{STORAGE}

Suspensions of campylobacter in broth were kept at approximately $-190^{\circ} \mathrm{C}$ but for day-to-day use were stored at $-20^{\circ} \mathrm{C}$ in $10 \%$ glycerol broth.

INCUBATION

All cultures were incubated in an atmosphere in which one-half to two-thirds of the air was extracted and replaced with $10 \% \mathrm{CO}_{2}$ in nitrogen.

\section{ANTISERA}

One strain was selected from each of six outbreaks for the preparation of antisera. We have tentatively referred to the heat-labile antigens and their corresponding antisera as ' $\mathrm{H}$ ', and to the heat-stable antigens and their corresponding antisera as ' $O$ '.

1 ' $O H$ ' antisera were raised in rabbits by a course of intravenous injections of formolised suspensions

Received for publication 7 January 1980 without the use of adjuvants. The organisms were grown for $18-24$ hours at $36^{\circ} \mathrm{C}$ on moist nutrient agar (Oxoid CM 271) slopes in $200 \mathrm{ml}$ 'medical flats'. The growth was washed off in normal saline $(0.85 \%$ $\mathrm{Na} \mathrm{Cl)} \mathrm{containing} 0.3 \%$ formalin, and this suspension, suitably diluted, was used for immunisation: day $10.5 \mathrm{ml}$, day $31.0 \mathrm{ml}$, day $51.5 \mathrm{ml}$-all calibrated to Brown's tube Nos 1-2; day $81 \mathrm{ml}$, day 10 $1.5 \mathrm{ml}$, day $122.0 \mathrm{ml}$-all calibrated to Brown's tube Nos 2-3. Most sera had ' $H$ ' and ' $O$ ' agglutinins and needed absorption with heated organisms to remove the homologous ' $\mathrm{O}$ ' antibodies when used for ' $\mathrm{H}$ ' agglutination.

2 ' $O$ ' antisera were raised in rabbits by a similar course of intravenous injections of a saline suspension of organisms heated at $100^{\circ} \mathrm{C}$ for 15 minutes. The organisms had previously been grown on nutrient agar plates (Oxoid CM 271) incubated for 18-24 hours at $36^{\circ} \mathrm{C}$.

3 Presumptive ' $H$ ' agglutination (heat labile): Agglutinating suspensions were made by a modification of the method used by Watson et al. ${ }^{2}$ Strains were grown for $18-24$ hours at $42^{\circ} \mathrm{C}$ on slightly moist blood agar plates (Oxoid CM 271). The growth from three blood agar plates $(9 \mathrm{~cm}$ Petri dish) was suspended in $15 \mathrm{ml}$ of normal saline containing $0.3 \%$ formalin and after the clumps had been allowed to settle overnight the supernatant was removed and used as the agglutinating suspension (approximately Brown's tube No. 1 or 2). Tests were done in Dreyer's tubes with $0.3 \mathrm{ml}$ of serum dilution in normal saline and $0.3 \mathrm{ml}$ of agglutinating suspension. The results were read after 4 hours' incubation at $37^{\circ} \mathrm{C}$ in a water bath.

4 Presumptive ' $O$ ' agglutination (heat stable): Strains were grown for $18-24$ hours at $36^{\circ} \mathrm{C}$ on blood agar plates (Oxoid CM 271). The growth from a blood agar plate was suspended in $10 \mathrm{ml}$ of normal saline, heated at $100^{\circ} \mathrm{C}$ for 15 minutes, and then calibrated 
to approximately Brown's tube No. 2. Tests were done in $2 \times \frac{1}{2}$ inch tubes with $0.5 \mathrm{ml}$ of diluted serum and $0.5 \mathrm{ml}$ of suspension and read after overnight incubation in a water bath at $50^{\circ} \mathrm{C}$. For specificity, sera usually required absorption with an appropriate heterologous ' $O$ ' suspension. Organisms were grown overnight at $36^{\circ} \mathrm{C}$ on nutrient agar plates, allowing the growth from one $9 \mathrm{~cm}$ Petri dish for $0.1 \mathrm{ml}$ of undiluted serum. The growth was washed off in normal saline and then heated at $100^{\circ} \mathrm{C}$ for 15 minutes. The heated suspensions were centrifuged at $3000 \mathrm{rpm}$ for 20 minutes, and then the supernatant was discarded. Antiserum diluted 1/2.5 in normal saline was added to the deposit, mixed well, and left for $2 \frac{1}{2}$ hours at $50^{\circ} \mathrm{C}$ in a water bath, being shaken at intervals. Finally, the suspension was centrifuged at $3000 \mathrm{rpm}$ for 20 minutes, and the supernatant was stored at $4^{\circ} \mathrm{C}$ with thiomersal (final concentration 1/10 000) as a preservative.

Although the formolised and heated agglutinating suspensions remain stable for at least a few days they are prone to become rough on storage.

5 Bactericidal test: A suspension of organisms in broth (approximately Brown's tube No. 1 or 2, diluted 1/1000) was made from the overnight growth on blood agar. The test was performed in microtitre plates. One volume $(0.02 \mathrm{ml})$ of antiserum, one volume of fresh guinea-pig complement, and one volume of organism suspension were incubated together for 30 minutes at $37^{\circ} \mathrm{C}$. One volume from each well was then transferred to a dried blood agar plate, which was incubated overnight at $42^{\circ} \mathrm{C}$, and the presence or absence of growth was recorded. Unabsorbed antisera raised with formolised suspensions ('O H' sera) generally had high bactericidal titres $(>1 / 2000)$; sera raised with heated organisms ('O' sera) were found also to be bactericidal although the titres were generally lower, and these sera were not used for routine tests. The test was done at two serum dilutions, usually $1 / 200$ and $1 / 1000$. The

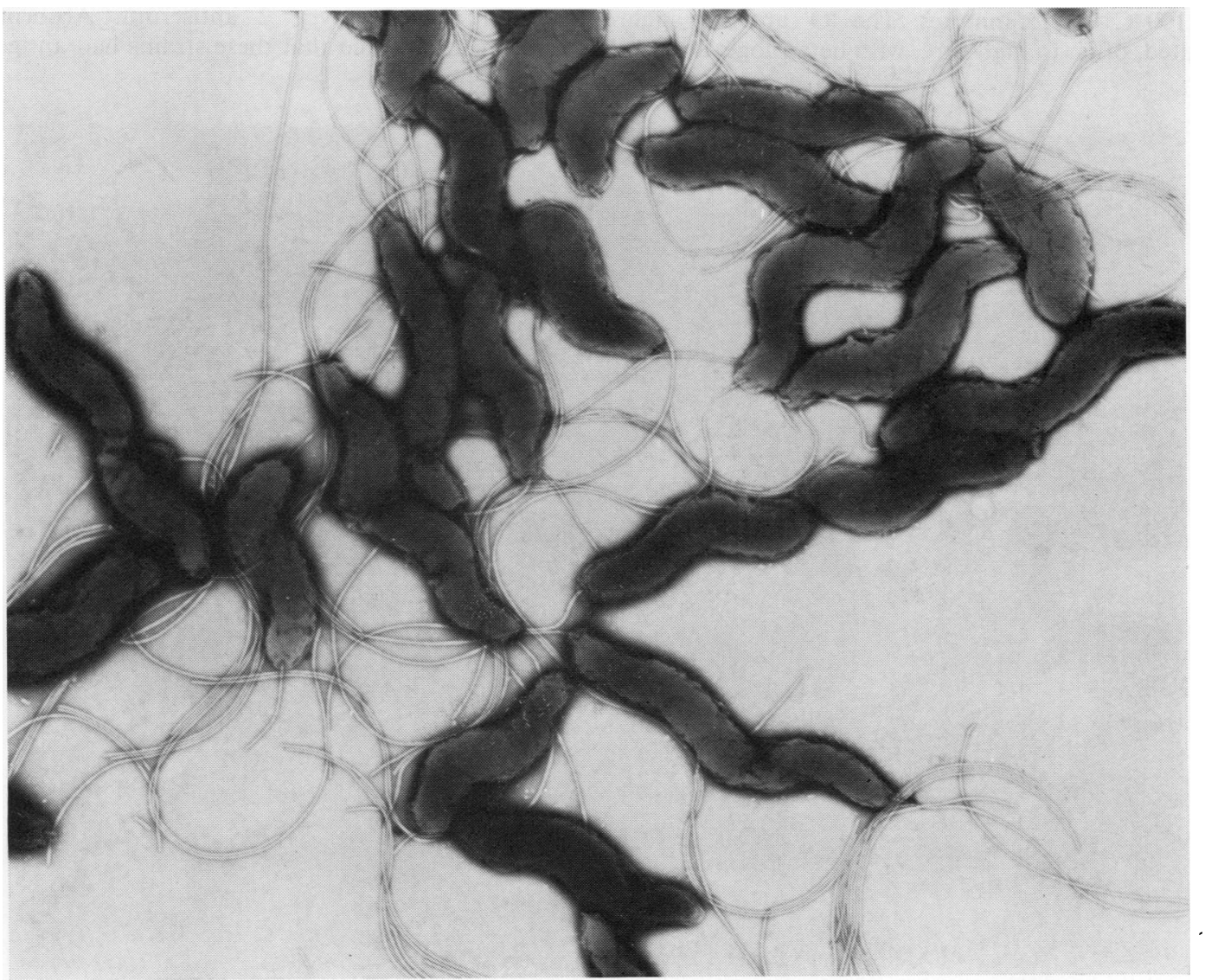

Fig. 1 Electron micrograph of formolised suspension of Campylobacter jejuni/coli. $\times 20000$. Stained with $3 \%$ phosphotungstic acid ( $p H 6 \cdot 5)$. 
specific reaction was represented by complete killing of the organisms at both dilutions. Partial killing at the lower dilution only was observed with certain heterologous strains.

\section{ELECTRON MICROSCOPY}

Campylobacter sp. are spiral or S-shaped organisms with a polar flagellum at each end (Fig. 1). Although the body structure shows little overall change after heating at $100^{\circ} \mathrm{C}$ for 15 minutes, there is complete destruction of the flagella (Fig. 2).

\section{Results}

The results of testing by agglutination the selected strains with homologous and heterologous ' $H$ ' antisera are shown in Table 1 . The only strain to show cross-agglutination with heterologous antisera was the type 2 strain that also reacted with type 5 ' $H$ ' serum. The presumptive ' $H$ ' antigens were heat labile and were inactivated by heating suspensions to $100^{\circ} \mathrm{C}$ for 15 minutes. The ' $O$ ' antisera agglutinated, often to high titre, with heterologous as well
Table 1 Presumptive ' $H$ ' agglutination of selected 'type' strains with homologous and heterologous antisera

\begin{tabular}{|c|c|c|c|c|c|c|}
\hline \multirow{2}{*}{$\begin{array}{l}\text { Outbreak } \\
\text { strain }\end{array}$} & \multicolumn{6}{|c|}{ Reciprocal of titres of $\mathrm{H}$ antiserum to strain No. } \\
\hline & 1 & 2 & 3 & 4 & 5 & 6 \\
\hline $\begin{array}{l}1 \\
2 \\
3 \\
4 \\
5 \\
6\end{array}$ & $\begin{array}{r}400 \\
<\quad 50 \\
<50 \\
<50 \\
<50 \\
<50\end{array}$ & $\begin{array}{r}<50 \\
100 \\
<50 \\
<50 \\
<50 \\
<50\end{array}$ & $\begin{array}{rr}< & 50 \\
< & 50 \\
& 1280 \\
< & 50 \\
< & 50 \\
< & 50\end{array}$ & $\begin{array}{r}<50 \\
<50 \\
<50 \\
400 \\
<50 \\
<50\end{array}$ & $\begin{array}{r}<50 \\
100 \\
<50 \\
<50 \\
400 \\
<50\end{array}$ & $\begin{array}{r}<50 \\
<50 \\
<50 \\
<50 \\
<50 \\
\quad 200\end{array}$ \\
\hline
\end{tabular}

as homologous suspensions, but this was mainly eliminated by absorption (Table 2).

The results of the bactericidal test are shown in Table 3. The selected type strains were all killed by the corresponding antiserum at high dilution, and most of the heterologous antisera were without action. Two cross-reactions were observed. Type 2 strains were killed also by type 5 antiserum at high dilution, but type 5 strains were killed at low dilution only by type 2 antiserum. Absorption experiments showed that these strains had antigenic

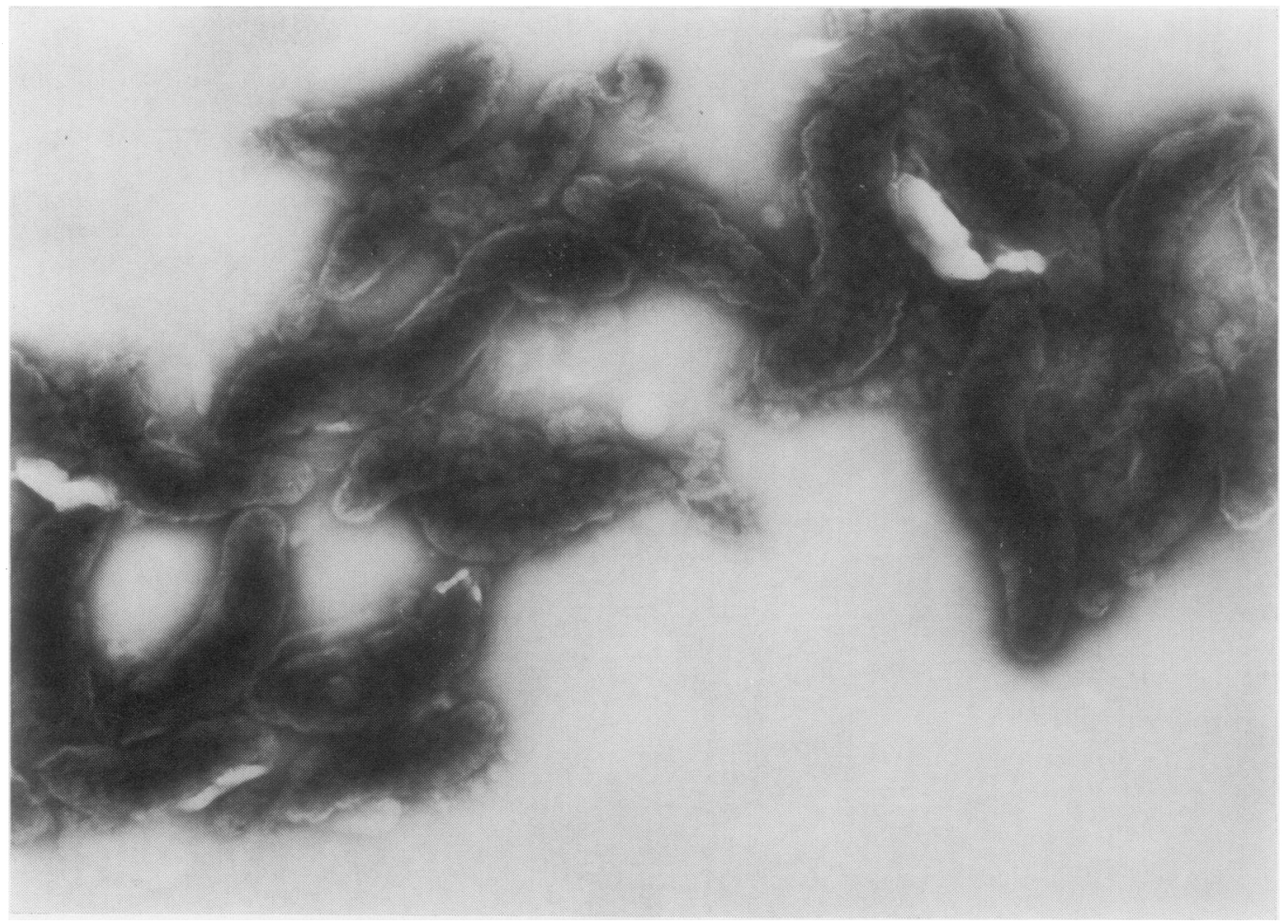

Fig. 2 Electron micrograph of suspension of Campylobacter jejuni/coli heated to $100^{\circ} \mathrm{C}$ for 15 minutes. $\times 25000$. Stained with $3 \%$ phosphotungstic acid (pH 6.5). 
Table 2 Presumptive ' $O$ ' agglutination of selected 'type' strains with homologous and heterologous antisera

\begin{tabular}{|c|c|c|c|c|c|c|}
\hline \multirow{2}{*}{$\begin{array}{l}\text { Outbreak } \\
\text { strain }\end{array}$} & \multicolumn{6}{|c|}{ Reciprocal of titres of $O$ antiserum to strain No. } \\
\hline & $I$ & 2 & 3 & 4 & 5 & 6 \\
\hline $\begin{array}{l}1 \\
2 \\
3 \\
4 \\
5 \\
6\end{array}$ & $\begin{array}{r}400 \\
<50 \\
<50 \\
<50 \\
<50 \\
<50\end{array}$ & $\begin{array}{r}<50 \\
800 \\
<50 \\
<50 \\
<50 \\
<50\end{array}$ & $\begin{array}{r}100 \\
<50 \\
800 \\
<50 \\
<50 \\
<50\end{array}$ & $\begin{array}{r}<100 \\
<100 \\
<100 \\
800 \\
<100 \\
<100\end{array}$ & $\begin{array}{r}<50 \\
<50 \\
<50 \\
<50 \\
4 \quad 400 \\
<\quad 50\end{array}$ & $\begin{array}{l}<50 \\
<50 \\
50 \\
<50 \\
<50 \\
800\end{array}$ \\
\hline
\end{tabular}

O 1 antiserum absorbed with type 2

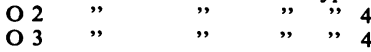

O 4 " " unabsorbed ,, ,

O 6 " " " " , 2, 3, and 4

Table 3 Bactericidal reactions of selected 'type' strains with homologous and heterologous antisera

\begin{tabular}{|c|c|c|c|c|c|c|}
\hline \multirow{2}{*}{$\begin{array}{l}\text { Outbreak } \\
\text { strain }\end{array}$} & \multicolumn{6}{|c|}{ Bactericidal activity of ' $\mathrm{OH}$ ' antiserum to strain No. } \\
\hline & 1 & 2 & 3 & 4 & 5 & 6 \\
\hline 1 & + & - & - & - & - & - \\
\hline 2 & - & + & - & - & + & - \\
\hline 3 & \pm & - & + & - & - & - \\
\hline 4 & 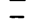 & - & - & + & - & - \\
\hline 5 & - & \pm & - & - & + & - \\
\hline 6 & - & $=$ & - & - & - & + \\
\hline
\end{tabular}

+ bactericidal activity at high dilution

\pm bactericidal at low dilution only

relationships but were not identical. Type 1 antiserum had slight activity against the type 3 strain, but type 3 antiserum was without action on type 1 strain.

\section{OUTBREAKS}

\section{No. 1 (Bradford) $)^{3} 1978$}

Fourteen persons developed enteritis over a threeweek period. These patients drank unpasteurised milk from one farm. Four strains from faeces were tested, and all gave titres of $>400$ with type 1 ' $H$ ' serum and titres of $>200$ with type 1 ' $O$ ' serum, and were killed at high dilution by type 1 ' $\mathrm{O} H$ ' serum. There were no significant cross-reactions with the heterologous sera.

\section{No. 2 (Aberdeen) 1979}

Over a period of one week, 204 persons developed enteritis associated with the consumption of inadequately pasteurised milk. Six faecal strains were tested; all gave titres of 50-100 with type 2 ' $H$ ' serum and titres of $>400$ with type 2 ' $O$ ' serum, and were killed by type 2 ' $\mathrm{O} H$ ' serum at high dilution. Most strains agglutinated with type 5 ' $\mathrm{H}$ ' serum at a titre of 50-100 and were also killed by type 5 'O $\mathrm{H}$ ' serum at a high dilution. There were no significant crossreactions with the heterologous ' $O$ ' sera.

\section{No. 3 (Arnside) $1978^{3}$}

Over a period of one week 63 persons developed enteritis and all had drunk raw milk from one farm. Strains from the faeces of five patients and four cows from the farm were tested. Five human strains and one cow strain were similar, giving titres of $>200$ with type 3 ' $H$ ' serum and titres of $>400$ with type 3 ' $O$ ' serum, and were killed at high dilution by type 3 'O H' serum. Three cow strains were different, giving titres of $<50$ with type 3 ' $\mathrm{H}$ ' and ' $\mathrm{O}$ ' sera and were not killed by type 3 ' $\mathrm{O} H$ ' serum. Five further cow strains were tested by the bactericidal method only, and one of these was a type 3 strain. ' $O$ ' antisera were made against two human strains from this outbreak, and mirror absorption showed that the ' $O$ ' antigens were identical. None of the type 3 strains tested showed significant cross-reactions with heterologous ' $\mathrm{H}$ ' and ' $\mathrm{O}$ ' sera, but all gave a minor bactericidal cross-reaction with type 1 ' $\mathrm{O} \mathrm{H}^{\prime}$ ' serum.

No. 4 (Lincoln) 1979

More than 90 persons developed enteritis over a period of three weeks, and the source of the infection was thought to be a contaminated raw milk supply. Strains from the faeces of seven patients were tested. Six of the strains gave titres of $>200$ with type 4 ' $H$ ' serum and titres of $>400$ with type 4 ' $O$ ' serum, and all were killed at high dilution by type 4 ' $\mathrm{O} \mathrm{H}$ ' serum; there were no cross-reactions with the heterologous sera. One strain was different, not reacting with type 4 serum.

\section{No. 5 (Luton) 1979}

This was a large outbreak in which over 2000 persons, mainly school children, developed enteritis over a period of about three weeks. The only factor that linked the cases was the milk supply where the efficiency of pasteurisation was open to doubt. Strains from the faeces of 13 patients were tested. Eight gave titres of $>100$ with type 5 ' $\mathrm{H}$ ' serum, 10 gave titres of $>200$ with the type 5 ' $O$ ' serum, and all 10 were killed at high dilution by type 5 ' $\mathrm{O}$ H' serum. Three strains were different and did not react with type 5 serum. None of the type 5 strains showed crossreactions by agglutination, but all were killed at low dilution by type 2 ' $\mathrm{O} H$ ' serum.

No. 6 (Maidstone) 1979

In a closed institution 14 persons developed enteritis over a period of four weeks, and there was evidence that this outbreak may have been milk-borne. Strains from the faeces of six patients were tested. All gave titres of $>100$ with type 6 ' $\mathrm{H}$ ' serum and 
titres of $>400$ with type 6 'O' serum, and were killed by type 6 ' $\mathrm{O} \mathrm{H}$ ' serum at high dilution. There were no cross-reactions with heterologous sera by the bactericidal test or by ' $\mathrm{H}$ ' agglutination, but the ' $O$ ' serum required absorption with three heterologous strains to remove all cross-reactions.

\section{Cambridge 1978}

In a closed institution 27 persons developed enteritis over a period of five days. All the patients had been working on a farm and were in contact with a herd of cows. Strains from the faeces of three patients were tested; all gave titres of $>200$ with type 3 ' $H$ ' serum and titres of $>400$ with type 3 ' $O$ ' serum, and were killed by type 3 ' $\mathrm{O} \mathrm{H}$ ' serum at high dilution. There was no cross-reaction with the other typing sera. Absorption of type 3 ' $O$ ' serum with a heated suspension of one of the Cambridge strains removed the ability of this serum to agglutinate the homologous ' $O$ ' suspension, confirming that the three strains from this outbreak were type 3.

\section{Discussion}

These results show that specific heat-labile and heatstable antigens may be detected in Campylobacter jejuni/coli strains. In the strains we have examined the heat-labile antigens of each type appeared to be different but type 2 and type 5 strains have a one-way antigenic relationship. After absorption the ' $O$ ' antisera gave type-specific agglutination and the major heat-stable antigens in these strains all appeared distinct, although many minor antigens may be shared. It is reasonable to suppose that a typing scheme based on the presence of major heat-labile and heat-stable antigens should be possible.

Using a bactericidal system with unabsorbed sera, the different type strains were readily distinguished from each other, and some minor antigenic relationships were observed between some strains. The cross-reaction between type 2 and type 5 on the presumptive ' $H$ ' agglutination system was repeated in the bactericidal system. It is unlikely that bacteri- cidal activity is directed against the flagella, and as both ' $\mathrm{OH}$ ' and ' $O$ ' sera were found to be bactericidal there may be another surface antigen involved in the bactericidal reaction.

Using these antisera 'epidemic' and 'non-epidemic' strains may be distinguished. On the occasion when bovine strains were also available two cows in the Arnside herd could be identified as the probable source of the strain contaminating the milk, whereas the strains from the other cows in the herd were different. In the large outbreak, No. 5 (Luton), at least two serotypes were isolated from the patients although we have prepared an antiserum with only one of these. In the Cambridge outbreak, the campylobacter strain involved was serotype No. 3, indicating that there may not be an impossibly large number of serotypes. This typing system worked well in single-source outbreaks, and its epidemiological value was confirmed in relating possible sources of infection. We have little experience of typing strains from sporadic infections but this may be possible with a wider selection of typing sera.

We are grateful to Drs WM Edgar, AL Furniss, TMS Reid, L Robertson, CED Taylor, RE Tettmar, and AT Willis, who kindly sent us strains from the outbreaks that they investigated, and to Professor JP Butzler and Dr MB Skirrow for their help and encouragement. Dr A Curry took the electron micrographs.

\section{References}

${ }^{1}$ Butzler JP, Skirrow MB. Campylobacter enteritis. Clin Gastroenterol 1979;8:737-65.

${ }^{2}$ Watson KC, Kerr EJC, McFadzean SM. Serology of human campylobacter infections. J Infection 1979;1 :151-8.

${ }^{3}$ Robinson DA, Edgar WM, Gibson GL, Matchett AA, Robertson L. Campylobacter enteritis associated with consumption of unpasteurised milk. $\mathrm{Br}$ Med $J$ 1979; 1:1171-3.

Requests for reprints to: Dr DM Jones, Public Health Laboratory, Withington Hospital, Manchester M20 8LR, UK. 